\title{
Ekstrak Etanol Bawang Hutan (Eleutherine bulbosa (Mill.) Urb.) Sebagai Hepatoprotektor
}

\author{
Sri Mulyani Sabang ${ }^{1}$, Niluh Puspita Dewi ${ }^{2}$ \\ ${ }^{1}$ Jurusan P.MIPA/Kimia Fakultas FKIP Universitas Tadulako Palu \\ ${ }^{2}$ Program Studi S1 Farmasi \\ Sekolah Tinggi Ilmu Farmasi (STIFA) Pelita Mas Palu.
}

\begin{abstract}
ABSTRAK
Telah dilakukan penelitian uji efek hepatoprotektor ekstrak umbi bawang hutan (Eleutherine bulbosa (Mill.) Urb.) bertujuan untuk mengetahui efek hepatoprotektor ekstrak etanol umbi bawang hutan terhadap tikus putih jantan induksi $\mathrm{CCl}_{4}$ dan mengetahui dosis efektif sebagai hepatoprotektor. Kandungan metabolik sekunder berpotensi sebagai antioksidan diduga dapat melindungi hati. Metode penelitian yang digunakan adalah metode eksperimen laboratorium dengan pengukuran kadar SGOT dan SGPT sebelum dan sesudah induksi. Hewan uji yang digunakana adalah tikus putih jantan, dibagi dalam 6 kelompok. Kelompok 1 sebagai kontrol normal, kelompok 2 diberikan sebagai kontrol negatif, kelompok 3 sebagai kontrol positif, dan kelompok 4, 5, 6 diberikan ekstrak etanol bawang hutan dosis 100, 200, $400 \mathrm{mg} / \mathrm{kg}$ BB. Perlakuan diberikan per oral sebelum diinduksi $\mathrm{CCl}_{4}$ Data SGOT dan SGPT dianalisis dengan uji $\mathrm{t}$ student untuk mengetahui perbedaan kadar SGOT dan SGPT sebelum dan sesudah induksi. Untuk mengetahui dosis efektif dilakukan uji statistik dengan Analisis Sidik Ragam (ANSIRA) dilanjutkan dengan uji Duncan. Hasil menunjukkan bahwa ekstrak umbi bawang hutan dosis 100. 200, dan $400 \mathrm{mg} / \mathrm{kg}$ BB memiliki efek hepatoprtektor dan dosis $100 \mathrm{mg} / \mathrm{kgBB}$ merupakan dosis yang efektif sebagai hepatoprotektor. Kandungan flavonoid yang terdapat dalam bawang hutan memiliki kemampuan antioksidan yang dapat meredam kerusakan akibat induksi $\mathrm{CCl}_{4}$.
\end{abstract}

Kata kunci : Hepatoprotektor, Ekstrak umbi bawang dayak (Eleutherine bulbosa (Mill.) Urb.), $\mathrm{CCl}_{4}$.

\section{PENDAHULUAN}

Pemakaian obat tradisional semakin berkembang pesat akhir-akhir ini. Perkembangan ini didukung oleh kecenderungan manusia melakukan pengobatan secara alami atau kembali ke alam . Salah satu tanaman yang memiliki banyak manfaat yaitu bawang hutan. Salah satu senyawa yang dikandung oleh bawang hutan yaitu flavonoid, dikenal sebagai salah satu substansi antioksidan yang berkekuatan sangat kuat hingga dapat menghilangkan efek merusak yang terjadi dalam tubuh. Fungsi flavonoid antara lain sebagai anti kanker, antivirus, anti inflamasi, mengurangi resiko penyakit kardiovaskuler, serta penangkap radikal bebas. ${ }^{4}$

Beberapa penelitian dan pengujian telah dilakukan untuk membuktikan khasiat bawang hutan diantaranya; penelitian Evi dkk., (2010) tentang penentuan aktivitas antioksidan ekstrak etanol bulbus bawang dayak (Eleutherine amaricana Merr.) dengan metode DPPH menunjukkan bawang dayak memiliki nilai antioksidan kuat dengan nilai $\mathrm{IC}_{50}$ sebesar 25,3339 ppm. Penelitian oleh Endang Evacuasiany dkk., tentang pengaruh ekstrak bawang berlian (Eleutherine americana Merr.) terhadap penurunan kadar glukosa 
darah pada mencit swiss webster jantan model hiperglikemia dengan dosis bawang berlian yaitu $100 \mathrm{mg} / \mathrm{kgBB}, 200 \mathrm{mg} / \mathrm{kgBB}$ dan $400 \mathrm{mg} / \mathrm{kgBB}$ dengan kontrol positif menggunakan obat glibenklamid menunjukan perbedaan yang tidak signifikan dari kontrol positif.

Berdasarkan hal tersebut maka dilakukan penelitian yang bertujuan untuk melihat efek dari ekstrak etanol umbi bawang hutan sebagai hepatoprotektor dan mengetahui dosis efektif yang berefek sebagai hepatoprotektor. Penelitian ini diharapkan dapat memberikan informasi kepada masyarakat mengenai efek dari ekstrak etanol umbi bawang dayak sehingga dapat dijadikan alternatif untuk pengobatan berbagai macam penyakit utamanya pada kerusakan hati.

\section{METODE PENELITIAN}

Pada penelitian ini digunakan bahan uji umbi bawang hutan (Eleutherine bulbosa (Mill) Urb). Determinasi bawang hutan dilakukan di UPT. Sumber Daya Hayati Universitas Tadulako Sulawesi Tengah. Hasil determinasi membuktikan bahwa bawang hutan yang digunakan dalam penelitian memiliki spesies Eleutherine bulbosa (Mill) Urb dari genus Eleutherine. Tanaman diperoleh dari dataran tinggi Matantimali, kabupaten Sigi Propinsi Sulawesi Tengah.

Alat yang digunakan: Batang pengaduk, Blender, Corong kaca, Cawan porselin, Erlenmeyer, Fotometer 5010 (Roche®), Gelas kimia 50 ml, Gelas ukur, Gunting, Kandang hewan, Mortir dan stamper, Pipet tetes, Rotavapor, Sentrifuge, Sonde oral, Tabung reaksi, Timbangan analitik, Wadah maserasi, Waterbath

Bahan yang digunakan: Aluminium foil, Aquadest, Asam asetat, Asam sulfat, Asam klorida, Betadine, Curcuma $\left(\mathrm{Soho}^{\circledR}\right)$, Etanol 96\%, $\mathrm{FeCl}_{3}$, Karbon tetraklorida $\left(\mathrm{CCl}_{4}\right)$, Kapas, Kertas saring, Minyak kelapa, Na-CMC 0,5\%, NaOH, Pereaksi Dragendrof, Pereaksi Mayer, Pereaksi Wagner, Reagen kit SGPT dan SGOT, Sarung tangan, Serbuk magnesium, Serbuk simplisia umbi bawang dayak (Eleutherine bulbosa (Mill) Urb), Silika gel.

\section{Prosedur Penelitian}

\section{Pembuatan Ekstrak}

Serbuk kering umbi bawang dayak ditimbang sebanyak 500 gram kemudian dimaserasi dalam etanol (96\%) selama \pm 3 hari sambil sesekali diaduk. Hasil maserasi dipisahkan, filtrat dirotavaporasi untuk memisahkan ekstrak dengan pelarut kemudian diuapkan kembali di atas penangas air hingga diperoleh ekstrak kental.

\section{Uji Fitokimia}

Uji penapisan fitokimia dimaksudkan untuk mengetahui kandungan metabolit sekunder yang terdapat didalam simplisia atau ekstrak. Uji ini merupakan suatu analisis kualitatif kandungan kimia tumbuhan atau bagian tumbuhan yang meliputi uji alkaloid, flavonoid, tanin, saponin, polifenol.

\section{Perlakuan Terhadap Hewan Uji}

Hewan uji yang digunakan dalam penelitian ini sebanyak 30 ekor tikus putih jantan (Rattus norvegicus) yang dibagi dalam 6 kelompok perlakuan, setiap kelompok terdiri atas 5 ekor tikus untuk setiap perlakuan. Tikus diadaptasikan selama 2 minggu untuk menyeragamkan pola hidup dan mencegah terjadinya stress. Selama masa adaptasi tikus diberi pakan standar dan minum. Sebelum perlakuan tikus dipuasakan selama 18 jam kemudian dilakukan pengambilan darah melalui ekor, untuk dilakukan pengukuran kadar 
awal SGOT dan SGPT tikus. Kelompok I sebagai kontrol sehat diberikan Na-CMC 0,5\%

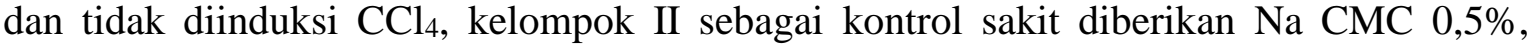
kelompok III sebagai kontrol positif diberikan curcuma dosis $100 \mathrm{mg} / \mathrm{kgBB}$, kelompok IV,V dan VI diberi ekstrak etanol umbi bawang dayak dengan dosis masing-masing 100 $\mathrm{mg} / \mathrm{kgBB}, 200 \mathrm{mg} / \mathrm{kgBB}$, dan $400 \mathrm{mg} / \mathrm{kgBB}$. Semua kelompok perlakuan diberikan selama 8 hari berturut-turut secara oral kemudian dilakukan kembali pengukuran kadar SGOT dan SGPT setelah perlakuan. Pada hari ke-9 kelompok II, III, IV, V, dan VI diinduksi dengan $\mathrm{CCl}_{4}$ dosis $1,3 \mathrm{ml} / \mathrm{kgBB}$ secara oral. Setelah 48 jam diinduksi $\mathrm{CCl}_{4}$, dilakukan pengambilan darah melalui ekor setelah dipuasakan selama $18 \mathrm{jam}$, dengan menggunakan tabung darah yang diberi antikoagulan EDTA sebanyak $2 \mathrm{ml}$ untuk diproses menjadi serum dengan cara disentrifuge dengan kecepatan 3000 rpm selama 10 menit. Serum diperoleh kemudian dilakukan pengukuran kadar SGOT dan SGPT.

\section{Pengukuran Kadar SGOT dan SGPT}

Darah tikus diambil kurang lebih $2 \mathrm{~mL}$ melalui vena ekor, darah dimasukkan kedalam tabung darah. Darah didiamkan selama 15 menit dan di sentrifug selama 10 menit dengan kecepatan $3000 \mathrm{rpm}$, serum yang diperoleh di pipet kedalam tabung reaksi. Jumlah serum yang dibutuhkan adalah $100 \mu \mathrm{L}$, kemudian ditambahkan reagen enzim $1000 \mu \mathrm{L}$ dan reagen substrat $200 \mu \mathrm{L}$ yang sebelumnya telah dipanaskan pada suhu $37^{\circ} \mathrm{C}$, campur hingga merata. Dibiarkan selama 1 menit. Diukur dengan menggunakan Fotometer 5010 $\left(\right.$ Rooche $^{\circledR}$ ) pada panjang gelombang $340 \mathrm{~nm}$ dengan faktor 1745. Ditunggu beberapa saat, kemudian dicatat hasil pengukuran kadar SGOT dan SGPT.

\section{Pengolahan Data}

Metode penelitian yang digunakan adalah metode eksperimental laboratorium dengan rancangan penelitian pre test- post test. Data yang diperoleh berupa kadar SGOT dan SGPT dianalisis secara statistik dengan uji $t$ berpasangan, uji ini digunakan untuk mengetahui efek hepatoprotektektor dari bawang hutan, untuk menentukan dosis yang efektif digunakan uji statistik analisis varians.

\section{HASIL DAN PEMBAHASAN}

Berdasarkan hasil pengujian fitokimia diperoleh bahwa ekstrak bawang dayak positif mengandung senyawa alkaloid, flavonoid, saponin, tanin, dan fenolik. Salah satu kandungan metabolik sekundernya yaitu flavonoid berpotensi sebagai hepatoprotektor karena memiliki kemampuan sebagai antioksidan yang dapat meredam radikal bebas akibat kerusakan yang disebabkan oleh karbon tetraklorida. Parameter yang digunakan dalam penelitian ini adalah pengukuran kadar SGOT dan SGPT. SGOT dan SGPT merupakan indikator untuk menentukan ada atau tidaknya gangguan pada hati. Hati merupakan pusat metabolisme tubuh dengan kapasitas cadangan yang besar, karena itu kerusakan sel hati secara klinis baru dapat diketahui dengan mengukur parameter fungsi berupa zat dalam peredaran darah yang dibentuk oleh sel hati yang rusak atau mengalami nekrosis. Seringkali pemeriksaan enzim menjadi satu-satunya petunjuk adanya penyakit hati yang dini atau setempat. Parameter yang biasa digunakan untuk melihat adanya gangguan fungsi hati antara lain: serum transaminase berupa SGOT (Serum Glutamic Oxaloacetic Transaminase) dan SGPT (Serum Glutamic Piruvic Transaminase), laktat dehidrogenase, serta bilirubin serum. Kadar SGPT dalam serum menjadi petunjuk yang lebih sensitif ke arah kerusakan hati karena sangat sedikit kondisi selain hati yang berpengaruh pada kadar SGPT dan dalam serum. ${ }^{2}$ Walaupun SGPT lebih khas untuk penyakit hati dibandingkan dengan SGOT tetapi kedua enzim tersebut selalu dipakai bersama-sama dalam evaluasi penyakit hati. 
Hasil Uji Efek Ekstrak Etanol Umbi Bawang hutan (Eleutherine bulbosa (Mill) Urb) Terhadap Kadar SGOT dan SGPT Tikus Putih Jantan

Pengujian efek ekstrak etanol umbi bawang hutan dosis $100 \mathrm{mg} / \mathrm{kgBB}, 200 \mathrm{mg} / \mathrm{kgBB}$ dan $400 \mathrm{mg} / \mathrm{kgBB}$ terhadap kadar SGOT dan SGPT tikus putih jantan yang diinduksi karbon tetraklorida $\left(\mathrm{CCl}_{4}\right)$ dilakukan untuk mengetahui efek protektif pemberian ekstrak etanol umbi bawang hutan yang diberikan selama 8 hari secara oral. Hasil pengukuran kadar SGOT dan SGPT disajikan dalam bentuk rerata dapat dilihat pada tabel 1 dan tabel 2.

Tabel 1. Hasil Pengukuran Kadar SGOT Pada Tikus Putih Jantan (Rattus norvegicus)

\begin{tabular}{|c|c|c|c|c|}
\hline Kelompok & No. & $\begin{array}{c}\text { Kadar Awal } \\
\text { (U/I) }\end{array}$ & $\begin{array}{c}\text { Kadar Setelah } \\
\text { Perlakuan }\end{array}$ & $\begin{array}{c}\text { Kadar akhir } \\
\text { (U/I) }\end{array}$ \\
\hline \multirow{5}{*}{$\begin{array}{l}\text { Kelompok Normal } \\
\text { (Na CMC 0,5\%) }\end{array}$} & Tikus 1 & 208,4 & 191,8 & 190,7 \\
\hline & Tikus 2 & 211,7 & 194,0 & 189,2 \\
\hline & Tikus 3 & 193,3 & 226,3 & 195,2 \\
\hline & Tikus 4 & 214,1 & 211,4 & 204,7 \\
\hline & Tikus 5 & 225,8 & 217,5 & 189,2 \\
\hline \multicolumn{2}{|l|}{ Rerata } & 210,66 & 208,2 & 193,8 \\
\hline \multirow{5}{*}{$\begin{array}{c}\text { Kelompok Sakit } \\
\left(\mathrm{CCl}_{4} 1,3 \mathrm{~mL} / \mathrm{kgBB}\right)\end{array}$} & Tikus 1 & 194,6 & 161,2 & 218,8 \\
\hline & Tikus 2 & 175,6 & 144,8 & 202,8 \\
\hline & Tikus 3 & 182,5 & 180,7 & 205,1 \\
\hline & Tikus 4 & 188,6 & 174,9 & 201,6 \\
\hline & Tikus 5 & 158,7 & 151,8 & 217,9 \\
\hline \multicolumn{2}{|l|}{ Rerata } & 180 & 162,68 & 209,24 \\
\hline \multirow{5}{*}{$\begin{array}{c}\text { Kelompok Positif } \\
\text { (Curcuma } 100 \\
\text { mg/kgBB) }\end{array}$} & Tikus 1 & 212,1 & 211,5 & 187,2 \\
\hline & Tikus 2 & 206,0 & 176,9 & 175,0 \\
\hline & Tikus 3 & 223,2 & 186,1 & 181,0 \\
\hline & Tikus 4 & 134,2 & 128,4 & 133,6 \\
\hline & Tikus 5 & 257,5 & 175,7 & 172,0 \\
\hline \multicolumn{2}{|l|}{ Rerata } & 206,0 & 175,72 & 169,76 \\
\hline \multirow{5}{*}{$\begin{array}{c}\text { Kelompok perlakuan } \\
\text { (EEUBD dosis } 100 \\
\mathrm{mg} / \mathrm{kgBB})\end{array}$} & Tikus 1 & 207,0 & 202,3 & 203,1 \\
\hline & Tikus 2 & 191,8 & 226,0 & 203,1 \\
\hline & Tikus 3 & 224,8 & 236,9 & 210,7 \\
\hline & Tikus 4 & 187,2 & 201,0 & 185,7 \\
\hline & Tikus 5 & 211,4 & 192,9 & 182,0 \\
\hline \multicolumn{2}{|l|}{ Rerata } & 204,44 & 211,82 & 196,92 \\
\hline \multirow{5}{*}{$\begin{array}{c}\text { Kelompok perlakuan } \\
\text { (EEUBD dosis } 200 \\
\text { mg/kgBB) }\end{array}$} & Tikus 1 & 168,1 & 181,2 & 176,2 \\
\hline & Tikus 2 & 173,0 & 170,2 & 131,3 \\
\hline & Tikus 3 & 181,2 & 171,3 & 164,0 \\
\hline & Tikus 4 & 169,8 & 161,6 & 177,5 \\
\hline & Tikus 5 & 191,7 & 204,1 & 194,7 \\
\hline \multicolumn{2}{|l|}{ Rerata } & $\mathbf{1 7 6 , 7 6}$ & 177,68 & 168,74 \\
\hline \multirow{5}{*}{$\begin{array}{c}\text { Kelompok perlakuan } \\
\text { (EEUBD dosis } 400 \\
\text { mg/kgBB) }\end{array}$} & Tikus 1 & 164,2 & 160,5 & 158,4 \\
\hline & Tikus 2 & 184,8 & 186,8 & 192,4 \\
\hline & Tikus 3 & 170,9 & 169,9 & 145,1 \\
\hline & Tikus 4 & 204,0 & 177,6 & 161,6 \\
\hline & Tikus 5 & 161,7 & 197,2 & 155,6 \\
\hline \multicolumn{2}{|l|}{ Rerata } & 177,12 & 178,4 & 152,62 \\
\hline
\end{tabular}




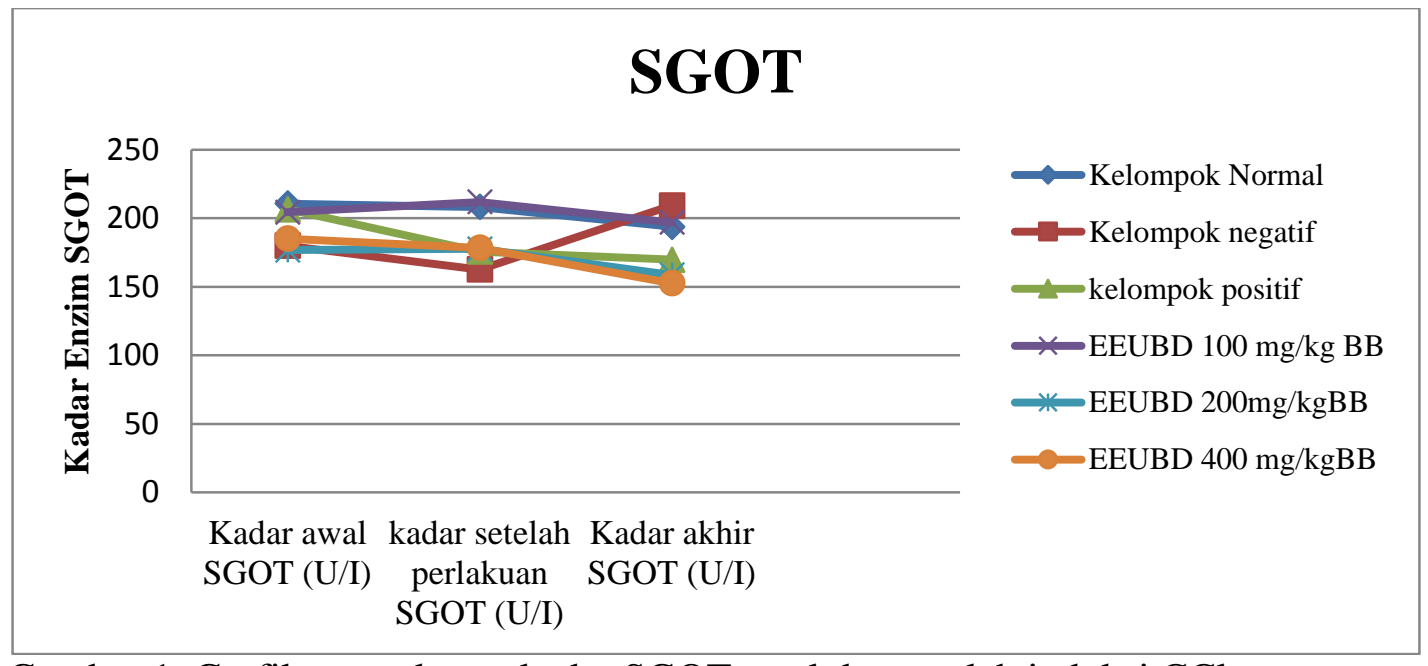

Gambar 1. Grafik pengukuran kadar SGOT awal dan setelah induksi $\mathrm{CCl}_{4}$.

Berdasarkan hasil perhitungan dengan uji $t$ students untuk kadar SGOT sebelum dan sesudah induksi karbon tetraklorida $\left(\mathrm{CCl}_{4}\right)$ terhadap tikus putih jantan dapat dilihat pada tabel 2 .

Tabel 2. Hasil Uji t Students Kadar SGOT Pada Tikus Putih Jantan (Rattus norvegicus)

\begin{tabular}{|l|c|c|l|}
\hline \multicolumn{1}{|c|}{ Kelompok } & thitung & ttabel & \multicolumn{1}{c|}{ Keterangan } \\
\hline $\begin{array}{l}\text { Kelompok Normal } \\
(\text { Na CMC 0,5\%) }\end{array}$ & 2,610 & 2,770 & $\begin{array}{l}\text { Tidak ada perbedaan } \\
\text { yang signifikan }\end{array}$ \\
\hline $\begin{array}{l}\text { Kelompok Sakit } \\
\left(\mathrm{CCl}{ }_{4} 1,3 \mathrm{~mL} / \mathrm{kgBB}\right)\end{array}$ & 3,816 & 2,770 & $\begin{array}{l}\text { Ada perbedaan yang } \\
\text { signifikan }\end{array}$ \\
\hline $\begin{array}{l}\text { Kelompok Positif } \\
(\text { Curcuma 100 mg/kgBB) }\end{array}$ & 2,642 & 2,770 & $\begin{array}{l}\text { Tidak ada perbedaan } \\
\text { yang signifikan }\end{array}$ \\
\hline $\begin{array}{l}\text { Kelompok perlakuan } \\
(\text { EEUBD 100 mg/kgBB) }\end{array}$ & 1,061 & 2,770 & $\begin{array}{l}\text { Tidak ada perbedaan } \\
\text { yang signifikan }\end{array}$ \\
\hline $\begin{array}{l}\text { Kelompok perlakuan } \\
(\text { EEUBD 200 mg/kgBB) }\end{array}$ & 0,834 & 2,770 & $\begin{array}{l}\text { Tidak ada perbedaan } \\
\text { yang signifikan }\end{array}$ \\
\hline $\begin{array}{l}\text { Kelompok perlakuan } \\
(\text { EEUBD 400 mg/kgBB) }\end{array}$ & 1,652 & 2,770 & $\begin{array}{l}\text { Tidak ada perbedaan } \\
\text { yang signifikan }\end{array}$ \\
\hline
\end{tabular}

Tabel 3. Hasil Pengukuran Kadar SGPT Pada Tikus Putih Jantan (Rattus norvegicus)

\begin{tabular}{|c|c|c|c|c|}
\hline Kelompok & No. & $\begin{array}{c}\text { Kadar } \\
\text { Awal } \\
\text { (U/I) }\end{array}$ & $\begin{array}{c}\text { Kadar } \\
\text { Setelah } \\
\text { Perlakuan }\end{array}$ & $\begin{array}{c}\text { Kadar Akhir } \\
\text { (U/I) }\end{array}$ \\
\hline \multirow{3}{*}{$\begin{array}{c}\text { Kelompok Normal } \\
\text { (Na CMC 0,5\%) }\end{array}$} & Tikus 1 & 94,1 & 83,1 & 80,0 \\
\cline { 2 - 5 } & Tikus 2 & 52,0 & 51,9 & 50,8 \\
\cline { 2 - 5 } & Tikus 3 & 54,5 & 49,2 & 45,2 \\
\cline { 2 - 5 } & Tikus 4 & 77,7 & 68,8 & 70,9 \\
\cline { 2 - 5 } & Tikus 5 & 89,4 & 64,5 & 60,9 \\
\hline
\end{tabular}




\begin{tabular}{|c|c|c|c|c|}
\hline Rerata & & 73,54 & 63,5 & 61,56 \\
\hline \multirow{2}{*}{$\begin{array}{c}\text { Kelompok Sakit } \\
(\mathrm{CCl} 41,3 \\
\mathrm{mL} / \mathrm{kgBB})\end{array}$} & Tikus 1 & 53,1 & 51,7 & 104,2 \\
\hline & Tikus 2 & 57,1 & 50,8 & 100,1 \\
\hline Kelompok & No. & $\begin{array}{c}\text { Kadar } \\
\text { Awal } \\
\text { (U/I) }\end{array}$ & $\begin{array}{c}\text { Kadar } \\
\text { Setelah } \\
\text { Perlakuan }\end{array}$ & $\begin{array}{c}\text { Kadar Akhir } \\
\text { (U/I) }\end{array}$ \\
\hline \multirow{3}{*}{$\begin{array}{c}\text { Kelompok Sakit } \\
\text { (CCl4 1,3 } \\
\text { mL/kgBB) }\end{array}$} & Tikus 3 & 29,0 & 30,2 & 107,6 \\
\hline & Tikus 4 & 64,7 & 64,1 & 121,6 \\
\hline & Tikus 5 & 39,9 & 39,1 & 119,7 \\
\hline Rerata & & 48,76 & 47,18 & 110,64 \\
\hline \multirow{5}{*}{$\begin{array}{c}\text { Kelompok Positif } \\
\text { (Curcuma } 100 \\
\text { mg/kgBB) }\end{array}$} & Tikus 1 & 83,9 & 82,9 & 71,9 \\
\hline & Tikus 2 & 91,8 & 84,8 & 60,1 \\
\hline & Tikus 3 & 79,0 & 74,3 & 70,4 \\
\hline & Tikus 4 & 82,0 & 74,1 & 71,4 \\
\hline & Tikus 5 & 94,4 & 77,0 & 67,7 \\
\hline Rerata & & 86,22 & 78,62 & 68,3 \\
\hline \multirow{5}{*}{$\begin{array}{c}\text { Kelompok } \\
\text { perlakuan } \\
\text { (EEUBD dosis } 100 \\
\mathrm{mg} / \mathrm{kgBB})\end{array}$} & Tikus 1 & 54,2 & 71,3 & 49,9 \\
\hline & Tikus 2 & 65,2 & 93,2 & 68,7 \\
\hline & Tikus 3 & 39,0 & 86,4 & 32,4 \\
\hline & Tikus 4 & 59,9 & 50,3 & 54,7 \\
\hline & Tikus 5 & 80,1 & 83,6 & 80,9 \\
\hline Rerata & & 59,68 & 76,96 & 57,32 \\
\hline \multirow{5}{*}{$\begin{array}{c}\text { Kelompok } \\
\text { perlakuan (EEUBD } \\
\text { dosis } 200 \\
\mathrm{mg} / \mathrm{kgBB})\end{array}$} & Tikus 1 & 64,1 & 61,0 & 59,0 \\
\hline & Tikus 2 & 86,3 & 75,2 & 35,5 \\
\hline & Tikus 3 & 95,8 & 72,7 & 60,8 \\
\hline & Tikus 4 & 60,3 & 60,0 & 53,6 \\
\hline & Tikus 5 & 93,4 & 92,2 & 80,7 \\
\hline Rerata & & 79,98 & 72,22 & 57,92 \\
\hline \multirow{5}{*}{$\begin{array}{c}\text { Kelompok } \\
\text { perlakuan (EEUBD } \\
\text { dosis } 400 \\
\mathrm{mg} / \mathrm{kgBB})\end{array}$} & Tikus 1 & 52,6 & 51,7 & 81,7 \\
\hline & Tikus 2 & 56,9 & 48,3 & 40,2 \\
\hline & Tikus 3 & 55,2 & 53,0 & 48,1 \\
\hline & Tikus 4 & 47,8 & 50,7 & 60,2 \\
\hline & Tikus 5 & 60,1 & 59,1 & 40,2 \\
\hline Rerata & & 54,52 & 52,56 & 54,08 \\
\hline
\end{tabular}




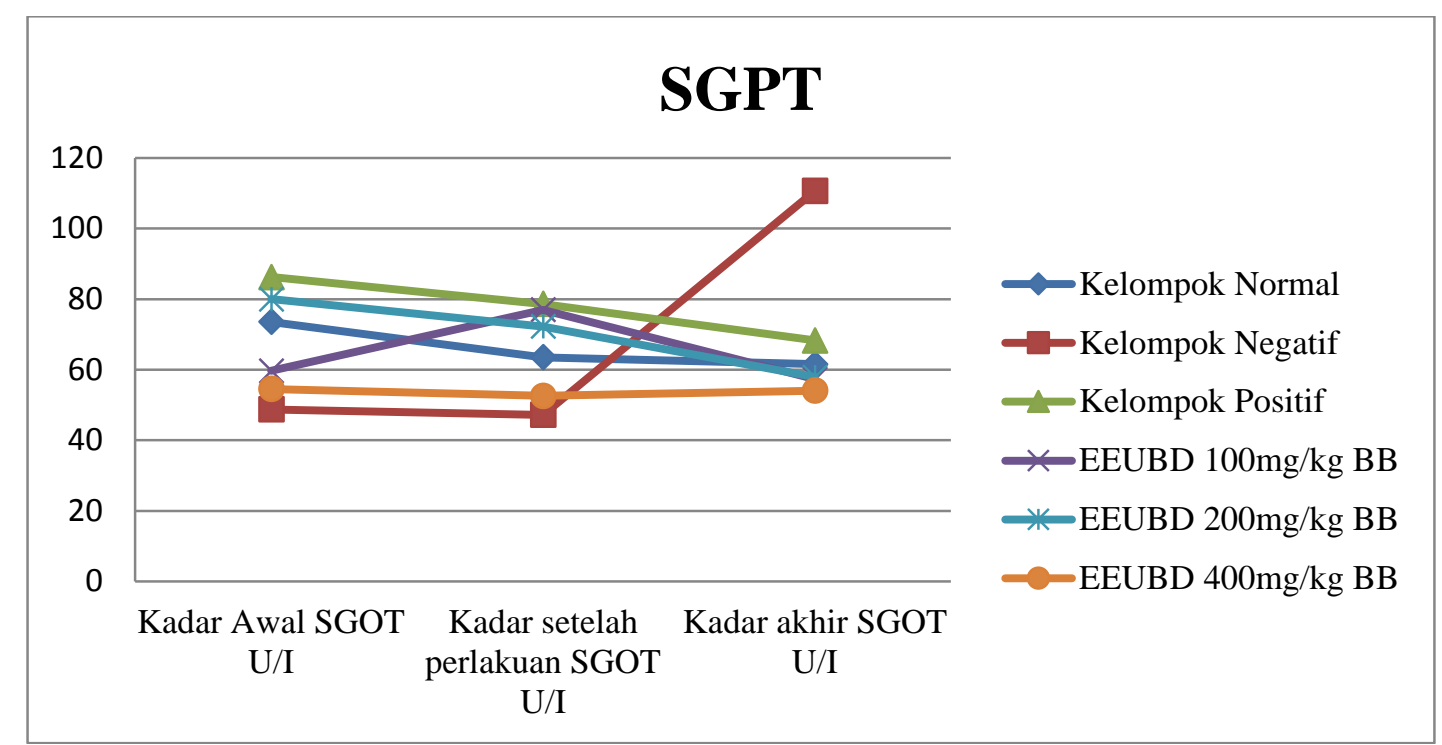

Gambar 2. Grafik pengukuran kadar SGPT awal dan setelah induksi $\mathrm{CCl}_{4}$.

Berdasarkan hasil perhitungan dengan menggunakan uji $t$ students pada kadar SGPT sebelum dan sesudah induksi karbon tetraklorida $\left(\mathrm{CCl}_{4}\right)$ terhadap tikus putih jantan didapatkan hasil yaitu dapat dilihat pada tabel 4 dibawah ini

Tabel 4. Hasil Uji t Students Kadar SGPT Pada Tikus Putih Jantan (Rattus norvegicus)

\begin{tabular}{|c|c|c|c|}
\hline Kelompok & thitung & t tabel & Keterangan \\
\hline $\begin{array}{l}\text { Kelompok Normal } \\
(\mathrm{Na} \text { CMC } 0,5 \%)\end{array}$ & 2,610 & 2,770 & $\begin{array}{l}\text { Tidak ada perbedaan } \\
\text { yang signifikan }\end{array}$ \\
\hline $\begin{array}{l}\text { Kelompok Sakit } \\
\left(\mathrm{CCl}_{4} 1,3 \mathrm{~mL} / \mathrm{kgBB}\right)\end{array}$ & 3,816 & 2,770 & $\begin{array}{l}\text { Ada perbedaan yang } \\
\text { signifikan }\end{array}$ \\
\hline $\begin{array}{l}\text { Kelompok Positif } \\
\text { (Curcuma } 100 \\
\mathrm{mg} / \mathrm{kgBB} \text { ) }\end{array}$ & 2,642 & 2,770 & $\begin{array}{l}\text { Tidak ada perbedaan } \\
\text { yang signifikan }\end{array}$ \\
\hline $\begin{array}{c}\text { Kelompok perlakuan } \\
\text { (EEUBD dosis } 100 \\
\mathrm{mg} / \mathrm{kgBB})\end{array}$ & 1,22 & 2,770 & $\begin{array}{l}\text { Tidak ada perbedaan } \\
\text { yang signifikan }\end{array}$ \\
\hline $\begin{array}{c}\text { Kelompok perlakuan } \\
\text { (EEUBD dosis } 200 \\
\mathrm{mg} / \mathrm{kgBB} \text { ) }\end{array}$ & 2,462 & 2,770 & $\begin{array}{l}\text { Tidak ada perbedaan } \\
\text { yang signifikan }\end{array}$ \\
\hline $\begin{array}{c}\text { Kelompok perlakuan } \\
\text { (EEUBD dosis } 400 \\
\mathrm{mg} / \mathrm{kgBB})\end{array}$ & 0,04 & 2,770 & $\begin{array}{l}\text { Tidak ada perbedaan } \\
\text { yang signifikan }\end{array}$ \\
\hline
\end{tabular}

Berdasarkan dari hasil uji statistik tersebut maka dapat diketahui bahwa ekstrak etanol umbi bawang hutan memiliki efek hepatoprotektor. Terbukti dari hasil analisis tidak ada perbedaan kadar SGOT maupun kadar SGPT sebelum dan sesudah diinduksi dengan karbon tetraklorida. Adanya efek protektif tersebut disebabkan karena dalam ekstrak umbi bawang hutan terkandung flavonoid yang berperan sebagai anti oksidan yang dapat meredam kerusakan yang disebabkab karbon tetra klorida.

Berdasarkan hasil uji statistik (ANOVA) untuk kadar SGOT dengan $\mathrm{db}=4$ dan $\alpha=$ 0,05 diperoleh nilai $F_{\text {tabel }}=3,24$ dan $F_{\text {hitung }}=3,17$, dengan demikian $F_{\text {hitung }}=3,17<$ Ftabel 
$=3,24$ berarti tidak terdapat perbedaan yang signifikan antar dosis yang digunakan dan kelompok yang diberi curcuma. Demikian juga untuk kadar SGPT dengan uji statistik ANOVA untuk $\mathrm{db}=4$ dan $\alpha=0,05$ diperoleh nilai $\mathrm{F}_{\text {tabel }}=3,24$ dan $\mathrm{F}_{\text {hitung }}=0,62$, dengan demikian $F_{\text {hitung }}=0,62<$ Ftabel $=3,24$ yang berarti tidak terdapat perbedaan yang signifikan dari ketiga dosis yang digunakan dan curcuma sebagai kontrol positif. Dengan demikian dosis yang efektif adalah dosis $100 \mathrm{mg} / \mathrm{kgBB}$, yaitu dosis yang rendah sudah memberikan efek yang sama dengan curcuma yang selama ini banyak digunakan sebagai hepatoprotektor.

Kemampuan ekstrak umbi bawang hutan sebagai hepatotprotektor disebabkan kandungan metabolit sekunder seperti flavonoid, dimana flavonoid memiliki kemampuan menyumbangkan atom hidrogen pada senyawa radikal sehingga dapat meredam efek merusak dari karbon tetraklorida selain itu kandungan antioksidan lain yang terdapat pada bawang dayak seperti naptaquinon (elecanacine, eleutherine, eleutherol, eleuthernone) dan antosianin merupakan antioksidan yang berperan dapat menetralkan radikal bebas.

\section{PENUTUP}

\section{Kesimpulan}

Berdasarkan hasil penelitian uji efek Hepatoprotektor ekstrak etanol umbi bawang hutan (Eleutherine bulbosa (Mill) Urb) terhadap kadar SGOT dan SGPT tikus putih jantan (Rattus norvegicus) yang diinduksi karbon tetraklorida $\left(\mathrm{CCl}_{4}\right)$ dapat disimpulkan bahwa : Ekstrak etanol umbi bawang hutan memiliki efek sebagai hepatoprotektor terhadap tikus putih jantan (Rattus norvegicus) yang diinduksi karbon tetraklorida $\left(\mathrm{CCl}_{4}\right)$, ditinjau dari kadar SGOT dan SGPT, dan dosis yang efektif yaitu dosis $100 \mathrm{mg} / \mathrm{kgBB}$.

\section{Saran}

Perlu dilakukan penelitian lebih lanjut dengan melakukan histopatologi hati hewan uji untuk melihat tingkat perbaikan sel hati yang ditimbulkan akibat pemberian ekstrak etanol umbi bawang dayak (Eleutherine bulbosa (Mill) Urb).

\section{DAFTAR PUSTAKA}

1. Galingging, R.Y. 2009 Bawang Dayak (Eleutherine americana Merr) Sebagai Obat Multifungsi. Hal. 2-3

2. Tangka,J., Wuisan,J., Tumbol,M. 2013. Uji Efek Hepatoprotektor Ekstrak etanol Daun Alpukat (persea americana Mill) Pada Tikus Putih (Rattus norvegicus)

3. Evi Mintowati Kuntorini, Maria Dewi Astuti. 2010. Penentuan Aktivitas Antioksidan Ekstrak Etanol Bulbus Bawang Dayak. FMIPA Universitas Lampung, hal 15

4. Indrawati, Niluh dkk. Bawang Dayak Si Umbi Ajaib Penakluk Aneka Penyakit. Agromedia Pustaka. Jakarta. Hal. 36-38

5. Kuntorini, Evi Mintowati. 2013. Kemampuan Antioksidan Bulbus Bawang Dayak Pada Umur Berbeda. Prosiding Seminar, FMIPA Universitas Lampung, Hal, 1

6. Saraswati, Endari Dewi. 2012. Mengidentifikasi Antioksidan:Polifenol. Fak. Teknologi Industri Pettanian, Universitas Padjadjaran. Bandung. Hal. 1

7. Surya, Hermawan. 2009. Efek ekstrak buah mengkudu (Morinda citrifolia. L) terhadap kadar enzim sgot dan sgpt pada mencit dengan induksi karbon tetraklorida. Skripsi. Fakultas kedokteran, Universitas Sebelas Maret. Surakarta.

8. Sacher dan McPerson. 2002. Tinjauan Kimia Hasil Pemeriksaan Laboratorium. Edisi 11. Penerbit buku kedokteran EGC. Jakarta. Hal: 369-370

9. Amirudin R. 2006. Fisiologi dan Biokimia Hati. Dalam: Buku Ajar Ilmu Penyakit Dalam.Jilid II. Edisi IV. Jakarta: Balai Penerbit FKUI,p : 417 
10. Bachri, Moch.saiful. 2011.Efek hepatoprotektif Ekstrak Metanol Jahe Merah (Zingiber officinale Roscoe) Pada Mencit Jantan yang Diinduksi CCl 4 . Hal 4-5

11. Meutia, Farah. 2011. Aktivitas Hepatoprotektor Ekstrak Metanol Daun Kari (Muraya koenigii L.) Pada Tikus Putih Sparague dawley. Skripsi. Fakultas Matematika dan Ilmu Pengetahuan Alam. Institut Pertanian Bogor. Bogor.

12. Panjaitan Ruqiah, Ekowati Handharyani, Chairul, Masriani, Zulfa Zakiah, Wasmen Manalu. 2007. Pengaruh Pemberian Karbon Tetraklorida Terhadap Fungsi Hati dan Ginjal Tikus. Makara Kesehatan Vol.11 No.1. Universitas Tanjung Pura. Pontianak. Hal 11-12

13. Mihin PY, Gandhi TR. 2008. Hepatoprotective Herbal Drug, Silymarin: from experimental pharmacologyto clinical medicine.

14. Girindra,A. 1989. Biokimia Patologi Hewan. Bogor: IPB Pr. 